\title{
Mitigation of Mild Steel Corrosion in Acid by Green Inhibitors: Yeast, Pepper, Garlic, and Coffee
}

\author{
Subir Paul and Bikash Kar \\ Department of Metallurgical and Material Engineering, Jadavpur University, Kolkata 700032, India \\ Correspondence should be addressed to Subir Paul, spaulxx@ymail.com
}

Received 3 October 2012; Accepted 19 October 2012

Academic Editors: C. Gu, C.-H. Hsu, and S. Umoren

Copyright () 2012 S. Paul and B. Kar. This is an open access article distributed under the Creative Commons Attribution License, which permits unrestricted use, distribution, and reproduction in any medium, provided the original work is properly cited.

Synthesized organic chemicals, used as inhibitors in mitigating the corrosion of huge quantities of steel articles, pose a major threat to the global environmental problems and health hazards. Naturally occurring products which had been used for natural medication purposes, since the human civilization, are found to inhibit corrosion of steel. Electrochemical studies of the effects of black pepper, garlic, yeast, and coffee on acid corrosion of steel have shown that the corrosion current decreases by manyfold with increase in concentration of the inhibitors. These green inhibitors have been found to get adsorbed maximum up to $70-90 \%$. The polarizing effect is more on cathodic reactions than on anodic reactions, acting as cathodic inhibitor, while a few behaves as anodic to mixed inhibitor. Mechanisms of adsorption are investigated by Frumkin, Temkin, and Langmuir isotherms. The free energy of adsorption is found to be between -15 and $-40 \mathrm{~kJ} / \mathrm{m}$ for most inhibitors, indicating the phenomena of physical adsorption.

\section{Introduction}

Mild steel articles are prone to severe degradation in $\mathrm{HCl}$. As a corrosion prevention and protection method, application of inhibitor is very popular. A number of heterocyclic compounds with $\mathrm{N}, \mathrm{S}$, and $\mathrm{O}$ as hetero atoms are proved to be effective corrosion inhibitors $[1,2]$, and the screening of synthetic heterocyclic compounds is still being continued. Though many synthetic compounds showed good anticorrosive activity, most of them are highly toxic to both human beings and environment. The safety and environmental issues of corrosion inhibitors arisen in industries have always been a global concern. These inhibitors may cause the reversible (temporary) or irreversible (permanent) damage to organ system, namely, kidneys or liver, or to disturb a biochemical process or to disturb an enzyme system at some site in the body. The toxicity may manifest either during the synthesis of the compound or during its applications. These toxic effects have led to the use of natural products as anticorrosion agents which are ecofriendly and harmless [3]. In recent days many alternative ecofriendly corrosion inhibitors have been developed, they range from rare earth elements [4] to organic compounds [5-8].

A few natural products such as plant extracts and animal proteins were reported [9] to have been used in pickling acid bath. But detailed studies of corrosion rate determination and adsorption of natural products as green inhibitors are very limited $[10,11]$. In the present investigation, mitigation of corrosion of low carbon steel has been studied with application of green inhibitors, namely, black pepper, coffee, garlic, and yeast.

\section{Experimental Methods}

2.1. Sample Preparation. Mild steel $(\mathrm{C}=0.24 \%, \mathrm{Mn}=0.72 \%$, $\mathrm{Si}=0.51 \%, \mathrm{~S}=.049 \%, \mathrm{P}=0.51 \%)$ specimens of size $6 \times$ $2 \mathrm{~mm}$ were cut from the bar sample and were polished with series of emery paper up to $3 / 0$ grade and subsequently cloth polished. The sample was cleaned with acetone before each polarization test.

2.2. Solution and Inhibitor Preparation. All the experiments were carried out at $25^{\circ} \mathrm{C}$, in $1 \mathrm{~N} \mathrm{HCl}$, prepared in double distilled deionized water, with or without different concentrations of various inhibitors.

Five different green inhibitors, black pepper, coffee, garlic, yeast, and tobacco were used. Black pepper is dried at $150^{\circ} \mathrm{C}$ to drive out moisture and pulverized using pestle and mortar and dissolved in $1 \mathrm{~N} \mathrm{HCl}$ at various concentrations. 
TABLE 1: Adsorption isotherm with different inhibitors in $\mathrm{HCl}$.

\begin{tabular}{|c|c|c|c|c|c|c|c|c|c|}
\hline & \multicolumn{3}{|c|}{ Langmuir } & \multicolumn{3}{|c|}{ Temkin } & \multicolumn{3}{|c|}{ Frumkin } \\
\hline & Reg. coefficient & K & $\begin{array}{c}\Delta G \\
\mathrm{~kJ} / \mathrm{m}\end{array}$ & Reg. coefficient & K & $\begin{array}{c}\Delta G \\
\mathrm{~kJ} / \mathrm{m}\end{array}$ & Reg. coefficient & $K$ & $\begin{array}{c}\Delta G \\
\mathrm{~kJ} / \mathrm{m}\end{array}$ \\
\hline Pepper & 0.910 & 49.20 & -19.7386 & 0.941 & 28707.81 & -35.6269 & 0.868 & 116.95 & -21.8984 \\
\hline Yeast & 0.895 & 264.85 & -23.9375 & 0.994 & $1.86 E+10$ & -69.0118 & 0.985 & 928.97 & -27.0681 \\
\hline Coffee & 0.967 & 16.14 & -16.9584 & 0.967 & 0.1 & -4.27533 & 0.904 & 769.13 & -26.5971 \\
\hline Garlic & 0.958 & 62.66 & -20.3417 & 0.968 & 1.472313 & -10.9845 & 0.937 & 17.1 & -17.102 \\
\hline
\end{tabular}

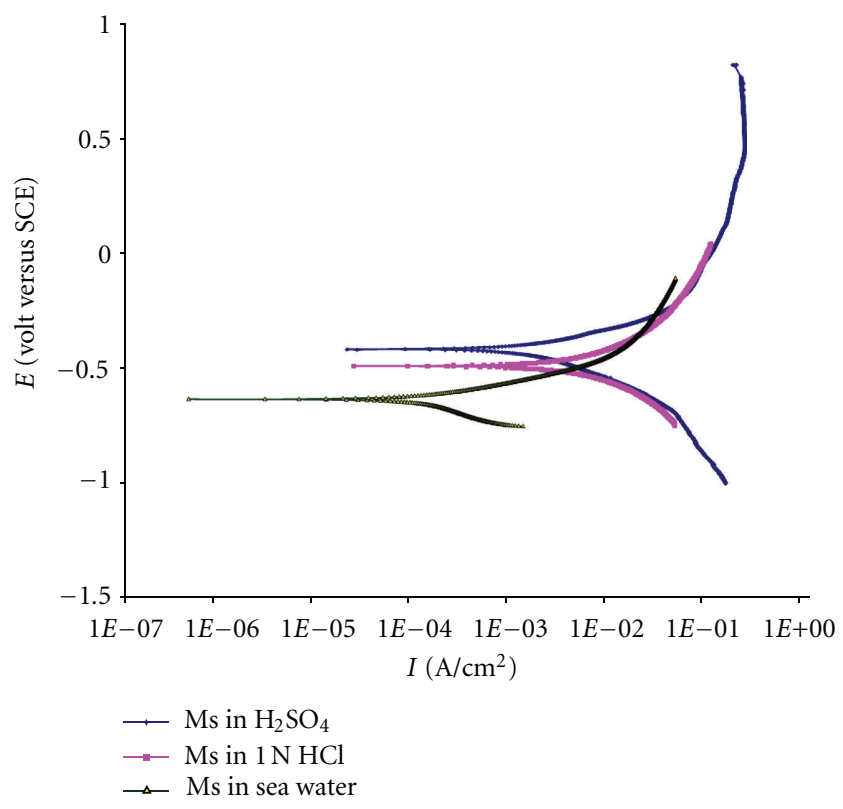

FIGURE 1: Polarization curves for mild steel in different for mild steel in various aqueous medium.

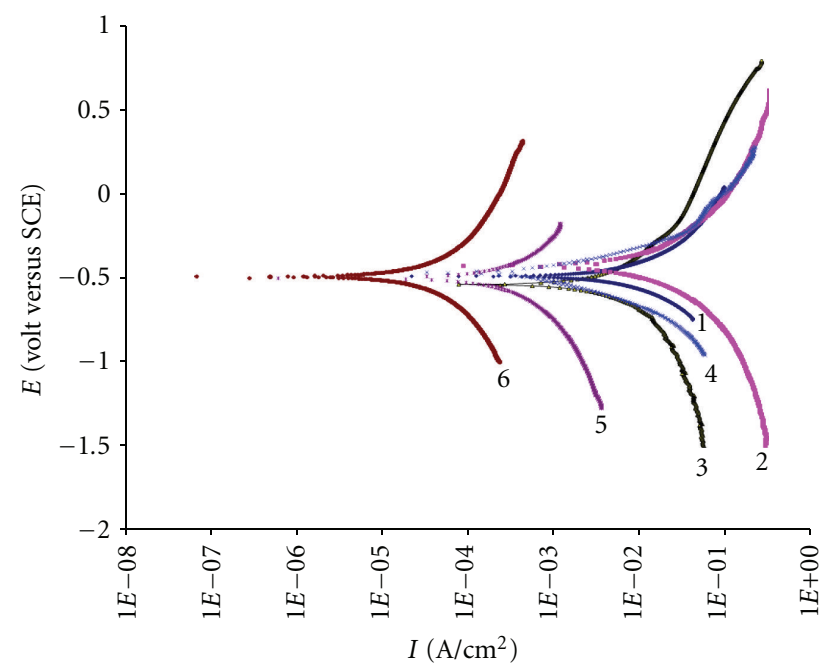

- (1) $\mathrm{Ms}$ in $1 \mathrm{~N} \mathrm{HCl} \quad$ (4) $100 \mathrm{ppm} b \mathrm{pp}$

- (2) $25 \mathrm{ppm} \mathrm{bp} \quad *$ (5) $150 \mathrm{ppm}$ bp

$\rightarrow$ (3) $50 \mathrm{ppm} \mathrm{bp} \quad$ • (6) $200 \mathrm{ppm} \mathrm{bp}$

FIGURE 2: Effect of different concentrations of black pepper as green inhibitor in mitigation of corrosion rate of steel in $\mathrm{HCl}$ acid.

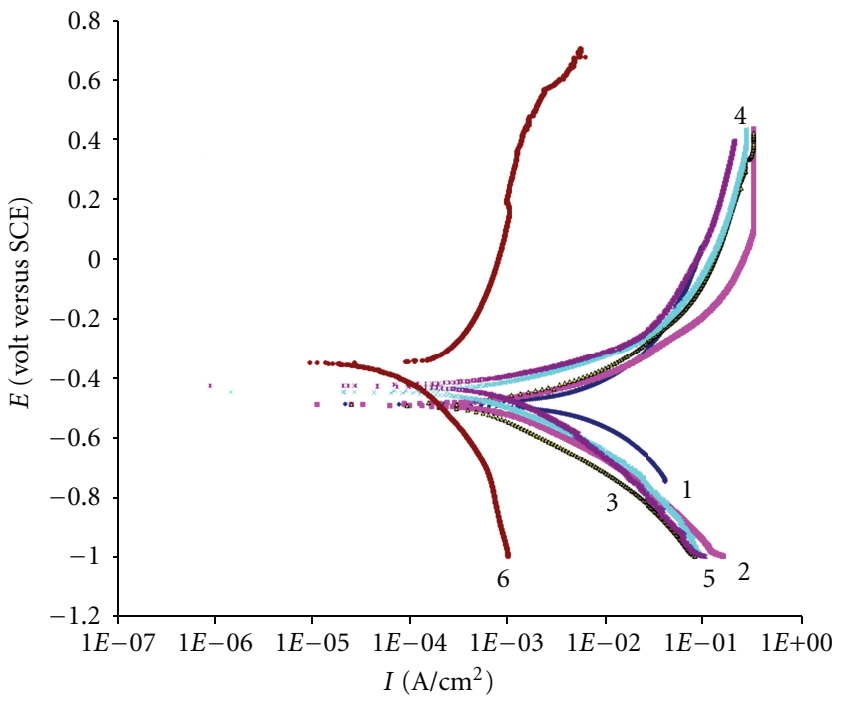

- (1) $\mathrm{Ms}$ in $1 \mathrm{~N} \mathrm{HCl} \times$ (4) $100 \mathrm{ppm}$ coffee

- (2) 25 ppm coffee * (5) $150 \mathrm{ppm}$ coffee

$\Delta$ (3) $50 \mathrm{ppm}$ coffee $\quad$ (6) $200 \mathrm{ppm}$ coffee

FIGURE 3: Effect of different concentrations of coffee as green inhibitor in mitigation of corrosion rate of steel in $\mathrm{HCl}$ acid.

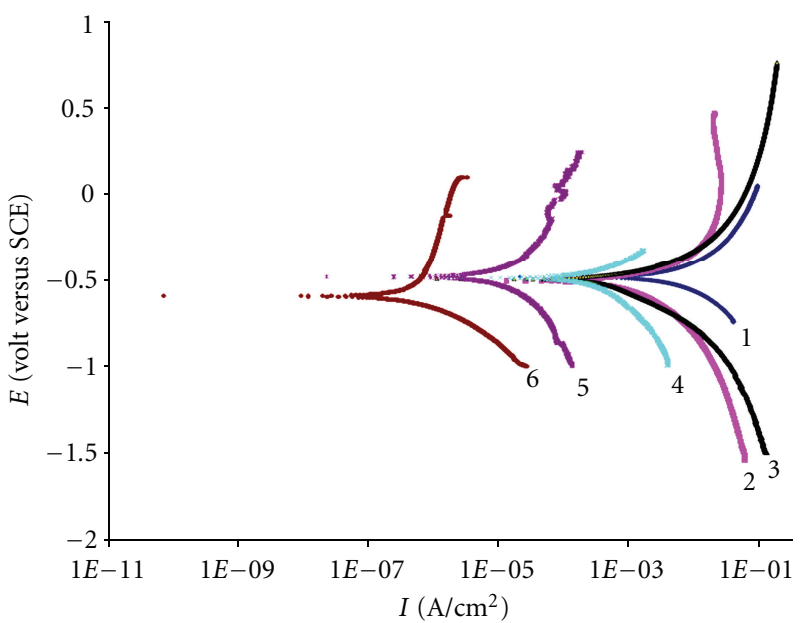

- (1) $\mathrm{Ms}$ in $1 \mathrm{~N} \mathrm{HCl} \quad \times$ (4) $100 \mathrm{ppm}$ garlic

- (2) $25 \mathrm{ppm}$ garlic $\quad$ (5) $150 \mathrm{ppm}$ garlic

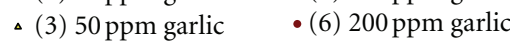

Figure 4: Effect of different concentrations of garlic as green inhibitor in mitigation of corrosion rate of steel in $\mathrm{HCl}$ acid. 


\begin{tabular}{lcc}
\multicolumn{3}{c}{ TABLE 2 } \\
\hline Inhibitors & $\begin{array}{c}\text { Temkin equation } \\
\text { interaction parameter }\end{array}$ & $\begin{array}{c}\text { Frumkin equation } \\
\text { interaction parameter } \\
\end{array}$ \\
\hline Pepper & 2.931719 & $a$ \\
Yeast & 17.00766 & 1.9445 \\
Coffee & 3.1832 & 0.864 \\
Garlic & 5.476534 & 0.7465 \\
\hline
\end{tabular}

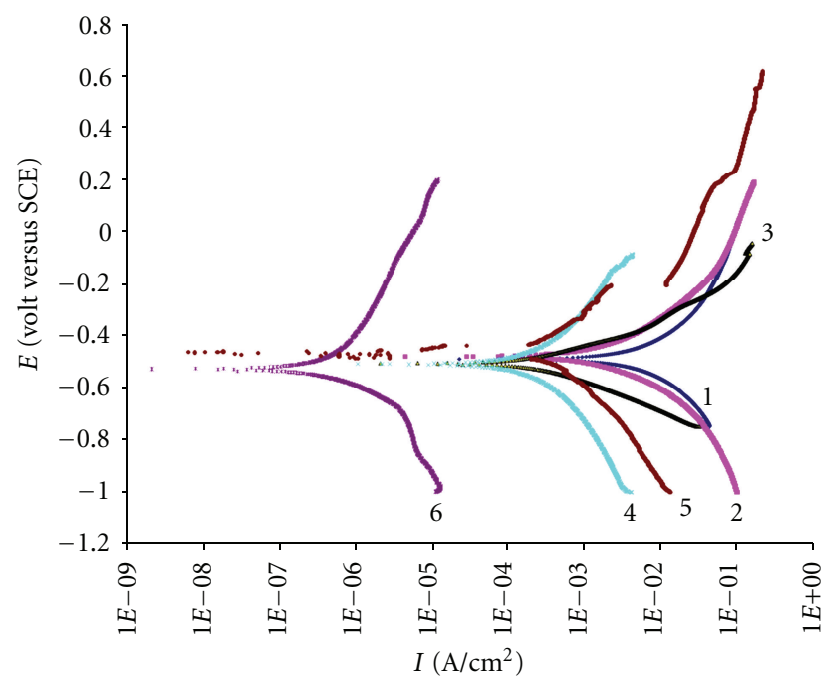

FIgURE 5: Effect of different concentrations of yeast as green inhibitor in mitigation of corrosion rate of steel in $\mathrm{HCl}$ acid.

Coffee powder was dried and different measured quantities of it were dissolved in acid to make various concentrations of the inhibitor. Garlic was pasted in mortar and squeezed to get the juice which was added in varying quantity to vary the concentration. Dry yeast was weighed in different quantities and added to $\mathrm{HCl}$. Tobacco leaf was dried in oven at $150^{\circ} \mathrm{C}$ to drive off moisture and then pulverized to -150 mesh. Required quantity of it was added in acid solution.

2.3. Electrochemical Polarization Study. Standard 3 electrodes corrosion cell was used to perform the electrochemical potentiostatic polarization tests on standard flat metal specimens. Polarization experiments were carried out as per ASTM standard methods (ASTM G 5: Potentiostatic and Potentiodynamic Anodic Polarization Measurements and ASTM G 59: Polarization Resistance Measurements) with a scan rate of $1 \mathrm{mV} / \mathrm{sec}$, using Gamry Potentiostat. Each of the experiments was repeated thrice to verify the consistency of the experimental data. Corrosion rates $\left(i_{\text {corr }}\right)$ were determined from the polarization plots of experimental data by Tafel's extrapolation and linear polarization methods.

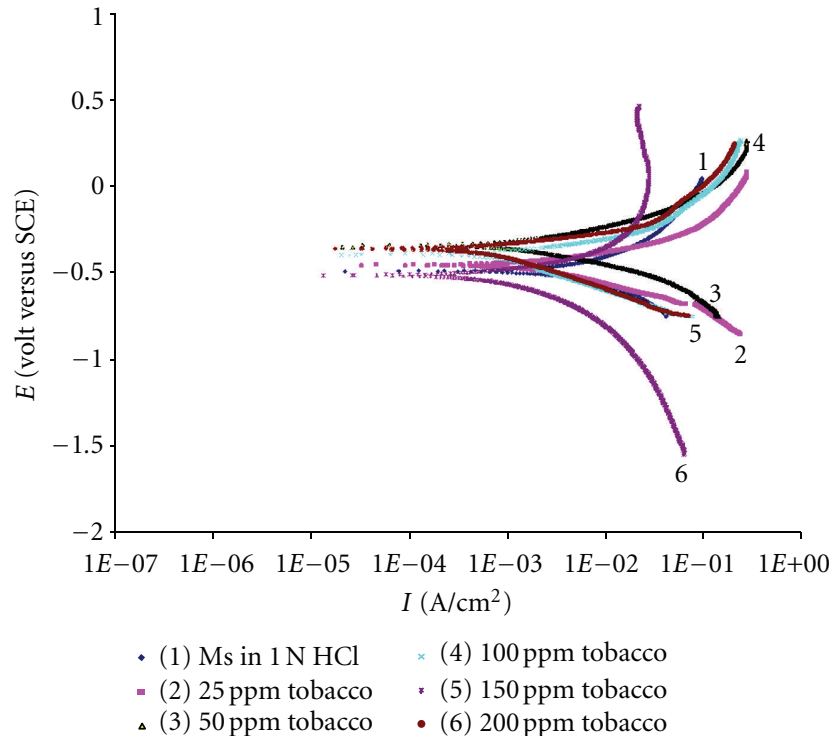

Figure 6: Effect of different concentrations of tobacco as green inhibitor in mitigation of corrosion rate of steel in $\mathrm{HCl}$ acid.

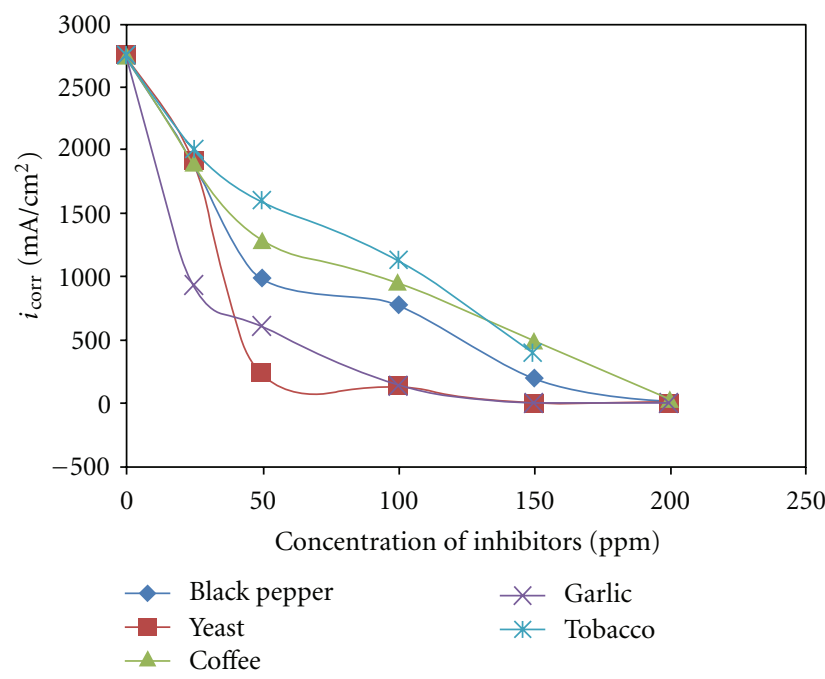

FIGURE 7: Comparison of different green inhibitors on mitigation of corrosion of MS in $\mathrm{HCl}$.

2.4. Adsorption Study. The fraction of inhibitor adsorbed $\theta$ was determined from the following equation:

$$
\theta=\left(1-\frac{i_{\text {In_corr }}}{i_{\text {corr }}}\right)
$$

where $i_{\text {In_corr }}$ and $i_{\text {corr }}$ are the corrosion current density with and without inhibitor, respectively.

\section{Results and Discussions}

Acids attack aggressively the articles and equipments made of low carbon steel. Different types of organic and inorganic inhibitors are used to mitigate the rate of the corrosion of the steel. It is interesting to find if the naturally occurring 


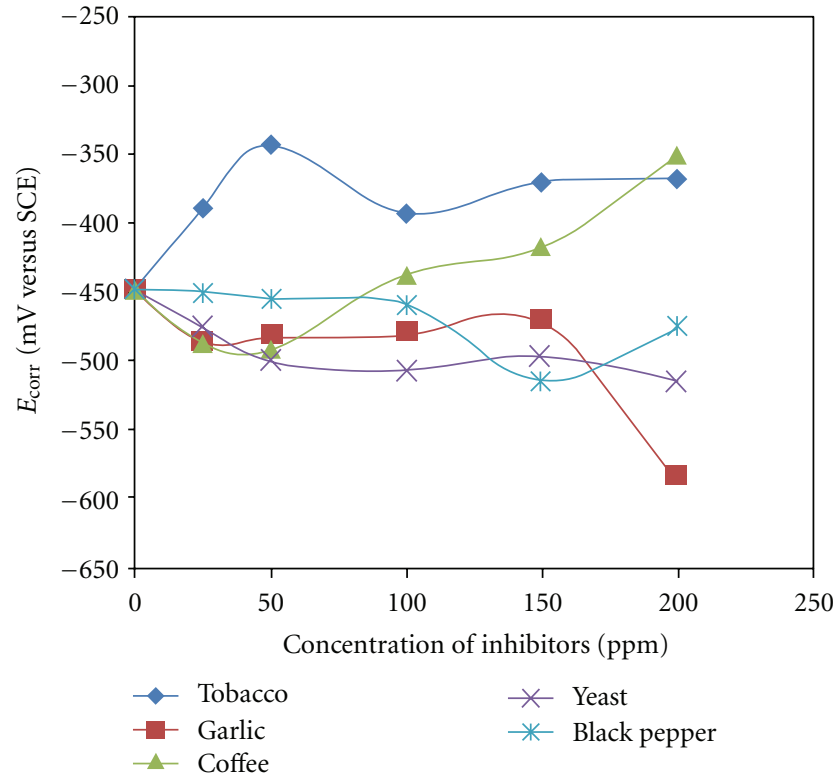

FIGURE 8: Comparison of corrosion potential of different inhibitors.

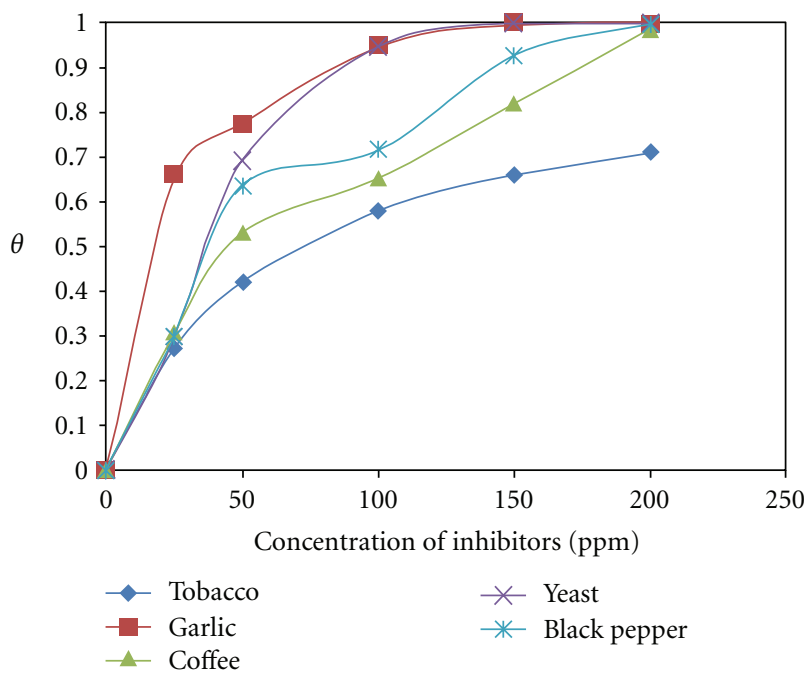

FIgURE 9: Comparison of fraction adsorbed with concentration of different inhibitors.

domestic products like black pepper, coffee, garlic, and yeast have any effect on electrochemical corrosion process of steel in acid.

Figure 1 compares corrosion rates of mild steel in three common aqueous environments, namely, $\mathrm{HCl}, \mathrm{H}_{2} \mathrm{SO}_{4}$, and sea water. It is seen that the corrosion rate of the steel is comparatively higher in $\mathrm{HCl}$ than in other aqueous environments. The effect of black pepper as green inhibitor with variation of concentration is shown in Figure 2. It is seen that the inhibitor reduces the corrosion rate and the degree of reduction increases with increase in concentration from $25 \mathrm{ppm}$ to $200 \mathrm{ppm}$. The corrosion rate decreases by over thousand times. The corrosion potential does not change much, indicating it is a mixed inhibitor. Coffee as

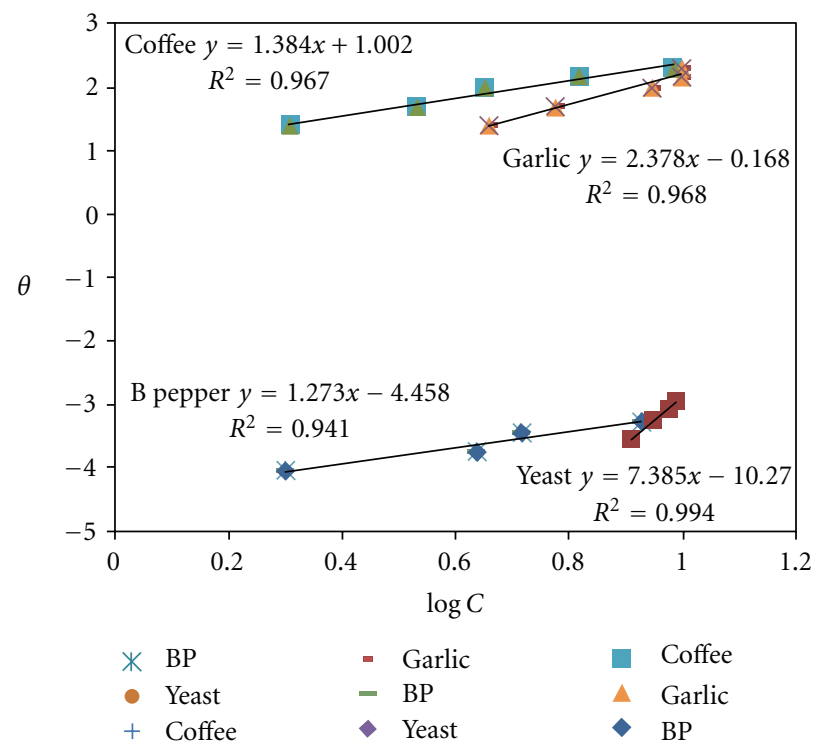

FIGURE 10: Temkin isotherm for different inhibitors in $\mathrm{HCl}$.

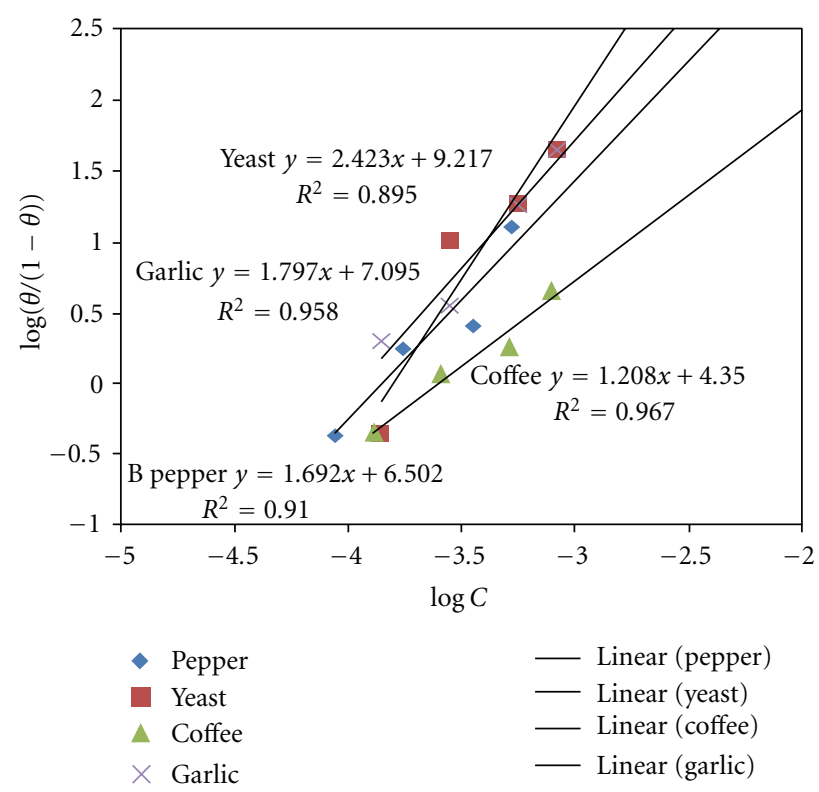

FIgURE 11: Langmuir isotherm for different inhibitors in $\mathrm{HCl}$.

green inhibitor is also effective in mitigation of corrosion (Figure 3) but its effect is less compared to black pepper. Similar study with garlic as inhibitor (Figure 4) shows it to be a very powerful inhibition of mild steel corrosion, the effect increases with concentration. The corrosion potential shifts in the negative direction at higher concentration, indicating it to be a cathodic inhibitor. Yeast is also seen to be a good green inhibitor for steel corrosion (Figure 5). The inhibitor is mixed to cathodic inhibitor. Tobacco can also act as green inhibitor (Figure 6) with corrosion potential shifting in the anodic region, indicating it is a cathodic inhibitor. Figure 7 displays a comparative corrosion mitigation with five different green inhibitors with variation 


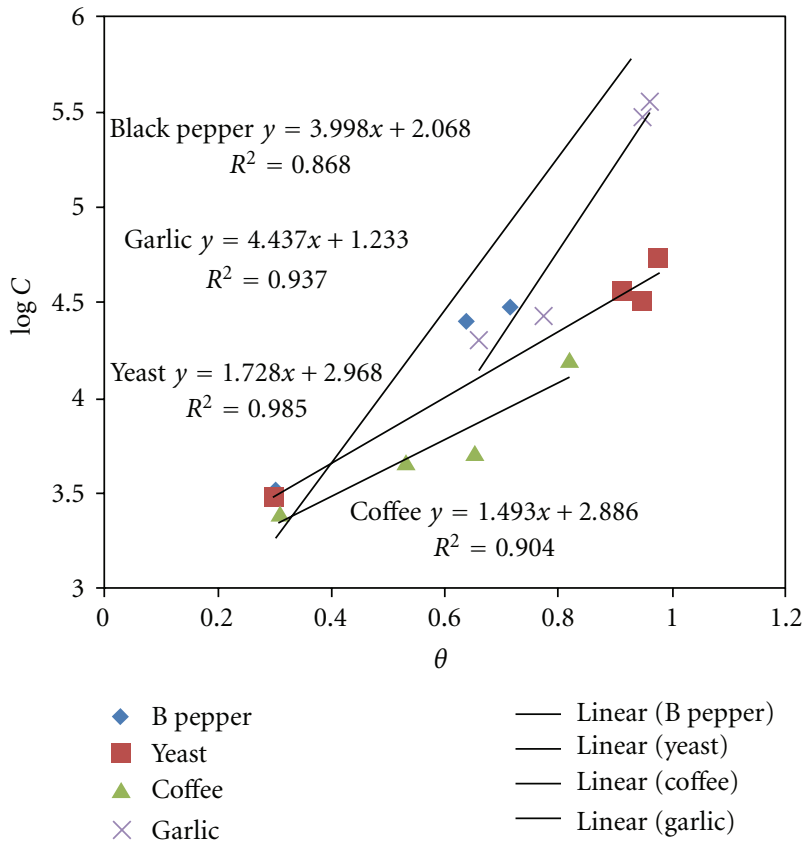

FIGURE 12: Frumkin Isotherm for different inhibitors in $\mathrm{HCl}$.

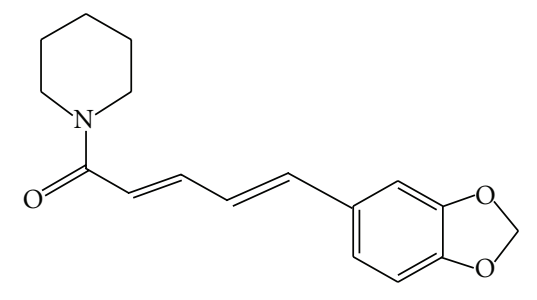

Molecular formula of Piperine

Figure 13

of their concentrations. It is seen while the effects of all the inhibitors in mitigating corrosion rate increase with concentration and reach minimum with $200 \mathrm{ppm}$ concentration, the effect of yeast and garlic is more powerful compared to other inhibitors. The inhibiting effect of tobacco is the least, so tobacco was left out for further experimentation. Figure 8 illustrates variation of corrosion potential with concentration for five different green inhibitors. It is seen that the corrosion potential shifts in the negative direction for garlic, black pepper, and yeast, indicating them as cathodic inhibitor, while it shifts in the positive direction for tobacco and coffee, indicating them as anodic inhibitor. It is also interesting to note that the type of the inhibitor changes with increase in concentration. For example, black pepper acts as a mixed inhibitor with corrosion potential almost remaining same for a concentration up to about $100 \mathrm{ppm}$ and thereafter it shifts towards anodic region, acting as cathodic inhibitor. Coffee initially acts as cathodic inhibitor but with increase in concentration over $50 \mathrm{ppm}$, it becomes an anodic inhibitor.

Figure 9 shows adsorption characteristics of the inhibitors with concentration. While most of the inhibitors<smiles>Cn1c(=O)c2c(ncn2C)n(C)c1=O</smiles>

Molecular formula of caffeine

FIgURE 14

get adsorbed over $90 \%$ at higher concentration, tobacco is adsorbed maximum up to $70 \%$. Further study with tobacco has been discarded.

3.1. Adsorption Study. Adsorption isotherms are very important in understanding the mechanism of inhibition of corrosion reaction. The most frequently used adsorption isotherms are Frumkin, Temkin, Freundlich, and Langmuir isotherms. Determination of adsorption isotherm equation that best fit the adsorption data helps to compute free energy of adsorption from the following equation:

$$
\Delta G_{\mathrm{ads}}=-2.303 R T \log \left(55.5 K_{\mathrm{ads}}\right),
$$

where $K_{\mathrm{ads}}$ is the adsorption equilibrium constant. The constant 55.5 is the molar concentration of water in the solution. If the calculated values of $\Delta G_{\text {ads }}$ are negative and less than the threshold value of $-40 \mathrm{~kJ} / \mathrm{mol}$, it confirms that the adsorption of inhibitors on mild steel is spontaneous and that physical adsorption mechanism is applicable.

3.2. Langmuir Adsorption Isotherm. The Langmuir isotherm is the first choice for most models of adsorption and has many applications in surface kinetics. Langmuir adsorption is valid for low coverage.

It is based on four assumptions.

(1) The surface of the adsorbent is uniform, that is, all the adsorption sites are equivalent.

(2) Adsorbed molecules do not interact.

(3) All adsorption occurs through the same mechanism.

(4) At the maximum adsorption, only a monolayer is formed: molecules of adsorbate do not deposit on other, already adsorbed, molecules of adsorbate, only on the free surface of the adsorbent.

These four assumptions are seldom all true: there are always imperfections on the surface, adsorbed molecules are not necessarily inert, and the mechanism is clearly not the same for the very first molecules to adsorb as for the last. The fourth condition is the most troublesome, as frequently more molecules will adsorb on the monolayer.

The equation

$$
\frac{\theta}{(1-\theta)}=K C
$$




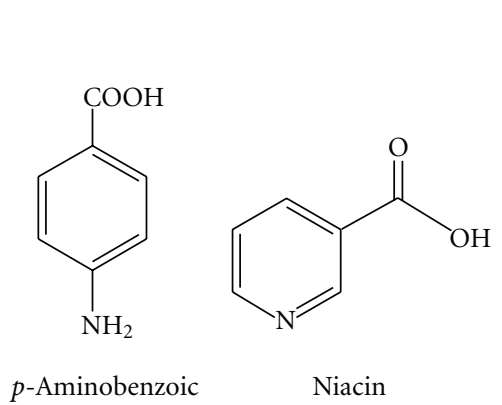

(a)

(b)

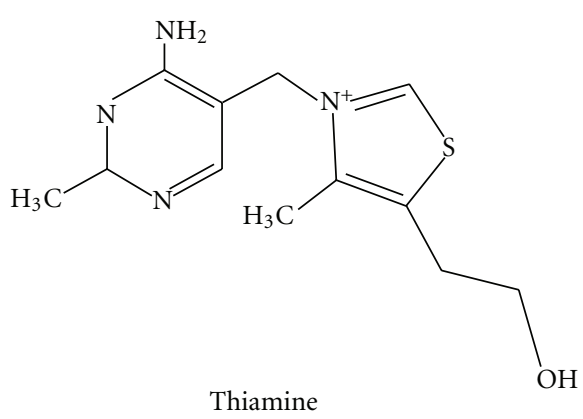

(c)

Figure 15

So

$$
\log \left[\frac{\theta}{(1-\theta)}\right]=\log c+\log K ;
$$

plotting $\log [\theta /(1-\theta)]$ versus $\log c$, intercept gives $\log K$.

3.3. Temkin Adsorption Isotherm. Temkin adsorption isotherm is only valid and effective at $0.2<\theta<0.8$. It assumes molecular interaction between adsorbed molecules. The equation is as follows:

$$
K C=e^{f \theta}, \quad \ln K+\ln C=f \theta,
$$

where $f$ is a molecular interaction parameter related to the molecular interactions in the adsorption layer as well as energetic inhomogeneity of the surface, and $C$ is the concentration in mole.

So $\log C=f \theta / 2.303-\log K$, plotting $\log C$ versus $\theta$, intercept $=-\log K$.

3.4. Frumkin Adsorption Isotherm. The Frumkin adsorption isotherm assumes that the electrode surface is inhomogeneous or that the lateral interaction effect is not negligible. The equation is as follows:

$$
\begin{gathered}
\frac{\theta}{(1-\theta)}=K c e^{2 a \theta}, \\
\ln \left[\frac{\theta}{(1-\theta) c}\right]=\ln K+2 a \theta,
\end{gathered}
$$

where $a$ is an interaction parameter, taking into account, the attraction $(a>0)$ or repulsion $(a<0)$ between the adsorbed species. For $a=0$ (no interaction) this isotherm becomes equivalent to the Langmuir isotherm. For $+\mathrm{ve} a$, adsorption energy decreases with $\theta$ whereas for negative $a$ adsorption energy decreases with $\theta$.

Plotting, $\ln [\theta /(1-\theta) c]$ versus $\theta$, intercept gives $\ln K$.

The adsorption data have been made to fit into the models of Temkin, Langmuir, and Frumkin adsorption isotherms as shown, respectively, in Figures 10, 11, and 12, with regression coefficient and equations given in the chart. It is seen in Figure 10 that adsorption data well fit the Temkin model with all four types of inhibitors with yeast being the best fit. Langmuir adsorption isotherms in Figure 11 show that the inhibitor yeast does not show much linearity while coffee and garlic are good fit. Frumkin isotherm is the best fit for yeast followed by garlic.

Table 1 displays the equilibrium constants and free energies for adsorption of different inhibitors. It is seen that all free energy values are negative indicating spontaneous adsorption of the inhibitors on steel surface and range of free energy values are between $-17 \mathrm{~kJ} / \mathrm{m}$ to $-35 \mathrm{~kJ} / \mathrm{m}$ except for yeast with Temkin model computed as $-69 \mathrm{~kJ} / \mathrm{m}$, indicating that the nature of adsorption is physical for black pepper, coffee, and garlic inhibitors.. Thus with these inhibitors, there will be no compound formation and the process is reversible. There may be multimolecular layer of adsorption of species. For yeast, being best fit with Temkin model, it is chemisorptions with higher adsorption energy of $-69 \mathrm{~kJ} / \mathrm{m}$. The effect of yeast in inhibiting corrosion was found to be maximum (Figure 7) with degree of adsorption reaching over $90 \%$ at $100 \mathrm{ppm}$ concentration (Figure 9). Thus there is a strong chemical bond formation between the constituents of yeast and steel surface blocking more number of cathodic sites (Figure 8, corrosion potential shifts towards negative potential.) and increasing the polarization of cathodic hydrogen evolution reaction, $\mathrm{H}^{+}+\mathrm{e}=\mathrm{H}$. The free energy of adsorption of black pepper on steel substrate is also high $(-35 \mathrm{~kJ} / \mathrm{m})$ fitting the Temkin model, indicating strong physical adsorption. The rate of corrosion has been drastically reduced with concentration (Figure 7). The inhibitor is a mixed variety (Figure 8) polarizing both anodic and cathodic reactions. At $100 \mathrm{ppm}$ concentration of the inhibitor, the fraction of adsorption is 0.70 (Figure 9) but the degree of corrosion reduction (Figure 7) is quite high. This may be due to the fact that inhibitor was adsorbed more on anodic sites than on cathodic sites, since the anodic area is generally much smaller than cathodic area. An inhibitor is generally assumed to be an anodic inhibitor if it can decrease the corrosion rate to a good extent with smaller fraction of adsorption. The inhibitor coffee follows Langmuir adsorption isotherm with free energy of $-16 \mathrm{~kJ} / \mathrm{m}$. It is a physical adsorption of monolayer with no interaction of adsorbed molecules. Corrosion rate decreases steadily with the increase in concentration of the inhibitor (Figure 7) 
due to more adsorption on uncovered sites which is the characteristic of Langmuir adsorption. The constituents of garlic also adsorb physically on metal surface following Temkin or Langmuir adsorption with energy in the order of -10 to $-20 \mathrm{~kJ} / \mathrm{m}$. Garlic is also very effective in reducing corrosion rate to very low at higher concentration (Figure 7). High percentage surface coverage (Figure 9) and corrosion potential shifting towards negative indicates that it blocks cathodic sites, increasing hydrogen overvoltage.

Table 2 displays the calculated interaction parameters of Temin and Frumkin equations. It is seen that interaction parameter a of the Frumkin equation is greater than zero for all the inhibitors, indicating that there is a force of attraction between the adsorbed species and there is no repulsion between them. This means that higher the concentration of the inhibitor, the more is the decrease in corrosion rate. This attractive force is found to be much more for black pepper and garlic than that for other two (Table 2) and that is why it is found (Figure 7) that the effect of these two inhibitors is more powerful at higher concentration. In case of Temkin adsorption equation, the interaction parameter $f$ (which is related to the molecular interactions in the adsorption layer as well as energetic inhomogeneity of the surface) is always positive and greater than 1 . So there exits molecular interaction among the species for all the inhibitors with highest being for yeast which showed maximum reduction in corrosion current (Figure 7 ). High energy of $-69 \mathrm{~kJ} / \mathrm{m}$ (Table 1) obtained with inhibitor supports the phenomena of chemisorptions with high molecular interaction.

Attempts have been made to understand the inhibiting effects of these green inhibitors from their chemical constituents. For example the main compound found in the black pepper [12] is the chemical substance Piperine (Figure 13) [13] which is a alkaloid, responsible for the pungency of black pepper.

Piperine forms monoclinic needles and is slightly soluble in water. It yields salts only with strong acids. Piperine has been found to inhibit many biochemical reactions in human body and drug metabolism. So this compound in black pepper seems to be inhibiting electrochemical metal dissolution reaction in acid solution.

Coffee contains a complex mixture of chemical compounds of caffeine, trigonelline, chlorogenic acid, phenolic acids, amino acids, carbohydrates, and minerals and volatile aroma components including organic acids, aldehydes, ketones, esters, amines, and mercaptans. Of these, Caffeine $\left(\mathrm{C}_{8} \mathrm{H}_{10} \mathrm{~N}_{4} \mathrm{O}_{2}\right)$, (Figure 14) is the major physiologically active substance. It is a bitter tasting alkaloid, soluble in water and in many organic solvents, and it appears as white crystals in pure form. It is the common name for trimethylxanthine (systematic name is 1,3,7-trimethylxanthine or 3,7-dihydro1,3,7-trimethyl-1H-purine-2,6-dione) $[14,15]$.

The inhibiting effect of Caffeine (Figure 14) present in coffee seems to be due to presence of aromatic rings with double bonds $\mathrm{O}$ group that make good inhibitor.

Garlic which is also known as Allium sativum [16], contains at least 33 sulfur compounds with maximum $(85 \%)$ being S-Allylcysteine sulfoxide $\left(\mathrm{C}_{6} \mathrm{H}_{11} \mathrm{NO}_{3} \mathrm{~S}\right)$ and 17 amino acids. The amount of sulphur concentration in garlic is higher than any other Allium species. The sulfur compounds are responsible both for garlic's pungent odor and many of its medicinal effects. For many years, sulfur compounds are being used for corrosion inhibition. For example, Thiourea $\mathrm{SC}\left(\mathrm{NH}_{2}\right)_{2}$ is known to be a very powerful chemical inhibitor for acid corrosion and is used for corrosion inhibition of steel articles in acids. So the presence of so many sulfur compounds and amines (amino acids) in garlic should be reason for mitigation of corrosion as found in present investigation.

Yeasts are eukaryotic microorganisms [17, 18]. More than one-half of the dry yeast consists of proteins and other nitrogenous bodies. Notable nitrogen base compounds [19] in the yeast that may inhibit steel corrosion in acids are p-Aminobenzoic acid $\mathrm{C}_{7} \mathrm{H}_{7} \mathrm{NO}_{2}$, Niacin $\mathrm{C}_{6} \mathrm{NH}_{5} \mathrm{O}_{2}$, and Thiamine hydrochloride $\mathrm{C}_{12} \mathrm{H}_{17} \mathrm{ClN}_{4} \mathrm{OS}$ (Figure 15). pAminobenzoic [20] (Figure 15(a)) consists of a benzene ring substituted with an amino group. It is slightly soluble in water.

Niacin [21], (Figure 15(b)) a colorless, water-soluble solid is a derivative of pyridine. Thiamine [22] (Figure 15(c)) is a water soluble sulfur containing vitamin. It also consists of amine group. It is well established that organic compounds having benzene ring with amine, diamine, and pyridine make very powerful corrosion inhibitor of steel in aqueous environment. This explains corrosion inhibiting property of yeast as found in the present investigation.

\section{Conclusion}

Naturally occurring products such as black pepper, coffee, garlic, and yeast, which are being used by human beings for centuries for cooking as well as medical purposes, can act as very good green inhibitors in mitigating the corrosion of steel articles in acids and hence can restrict the use of hazardous and toxic chemicals as inhibitors.

\section{References}

[1] F. Bentiss, M. Traisnel, and M. Lagrenee, "The substituted 1,3,4-oxadiazoles: a new class of corrosion inhibitors of mild steel in acidic media," Corrosion Science, vol. 42, no. 1, pp. 127$146,2000$.

[2] G. Schmitt, "Application of inhibitors for acid media: report prepared for the european federation of corrosion working party on inhibitors," British Corrosion Journal, vol. 19, no. 4, pp. 165-176, 1984.

[3] P. B. Raja and M. G. Sethuraman, "Natural products as corrosion inhibitor for metals in corrosive media-a review," Materials Letters, vol. 62, no. 1, pp. 113-116, 2008.

[4] M. A. Arenas, A. Conde, and J. J. De Damborenea, "Cerium: a suitable green corrosion inhibitor for tinplate," Corrosion Science, vol. 44, no. 3, pp. 511-520, 2002.

[5] M. Sanaa El-Sawy, M. Yosreya Abu-Ayana, and A. Fikry AbdelMohdy, "Some chitin/chitosan derivatives for corrosion protection and waste water treatments," Anti-Corrosion Methods and Materials, vol. 48, no. 4, pp. 227-235, 2001.

[6] E. Cano, P. Pinilla, J. L. Polo, and J. M. Bastidas, "Copper corrosion inhibition by fast green, fuchsin acid and basic 
compounds in citric acid solution," Materials and Corrosion, vol. 54, no. 4, pp. 222-228, 2003.

[7] Y. W. Kim, J. G. Kim, and D. J. Choi, "Development of a blended corrosion, scale, and microorganism inhibitor for open recirculating cooling systems," Materials and Corrosion, vol. 52, no. 9, pp. 697-704, 2001.

[8] G. Moretti, F. Guidi, and G. Grion, "Tryptamine as a green iron corrosion inhibitor in $0.5 \mathrm{M}$ deaerated sulphuric acid," Corrosion Science, vol. 46, no. 2, pp. 387-403, 2004.

[9] P. B. Raja and M. G. Sethuraman, "Natural products as corrosion inhibitor for metals in corrosive media-a review," Materials Letters, vol. 62, no. 1, pp. 113-116, 2008.

[10] C. H. Wu, H. N. Murthy, E. J. Hahn, H. L. Lee, and K. Y. Paek, "Efficient extraction of caffeic acid derivatives from adventitious roots of echinacea purpurea," Czech Journal of Food Sciences, vol. 26, no. 4, pp. 254-258, 2008.

[11] M. Badiea and K. N. Mohana, "Corrosion mechanism of steel and adsorption thermodynamics," Journal of Materials Engineering and Performance, vol. 18, no. 9, pp. 1264-1271, 2009.

[12] R. K. Bhardwaj, H. Glaeser, L. Becquemont, U. Klotz, S. K. Gupta, and M. F. Fromm, "Piperine, a major constituent of black pepper, inhibits human P-glycoprotein and $\mathrm{CYP}_{3} \mathrm{~A}_{4}$," Journal of Pharmacology and Experimental Therapeutics, vol. 302, no. 2, pp. 645-650, 2002.

[13] http://en.wikipedia.org/wiki/Piperine.

[14] http://www.coffee-tea.co.uk/caffeine-constituents.php.

[15] http://www.chemistryexplained.com/Bo-Ce/Caffeine.html.

[16] http://www.herballegacy.com/Motteshard_Chemical.html.

[17] http://chestofbooks.com/food/beverages/Alcohol-Properties/ Composition-Of-Yeast.html.

[18] E. A. Yamada and V. C. Sgarbieri, "Yeast (Saccharomyces cerevisiae) protein concentrate: preparation, chemical composition, and nutritional and functional properties," Journal of Agricultural and Food Chemistry, vol. 53, no. 10, pp. 39313936, 2005.

[19] http://openwetware.org/wiki/Composition_of_Yeast _Nitrogen_Base_\%28YNB\%29.

[20] http://en.wikipedia.org/wiki/4-Aminobenzoic_acid.

[21] http://en.wikipedia.org/wiki/Niacin.

[22] http://en.wikipedia.org/wiki/Thiamine. 

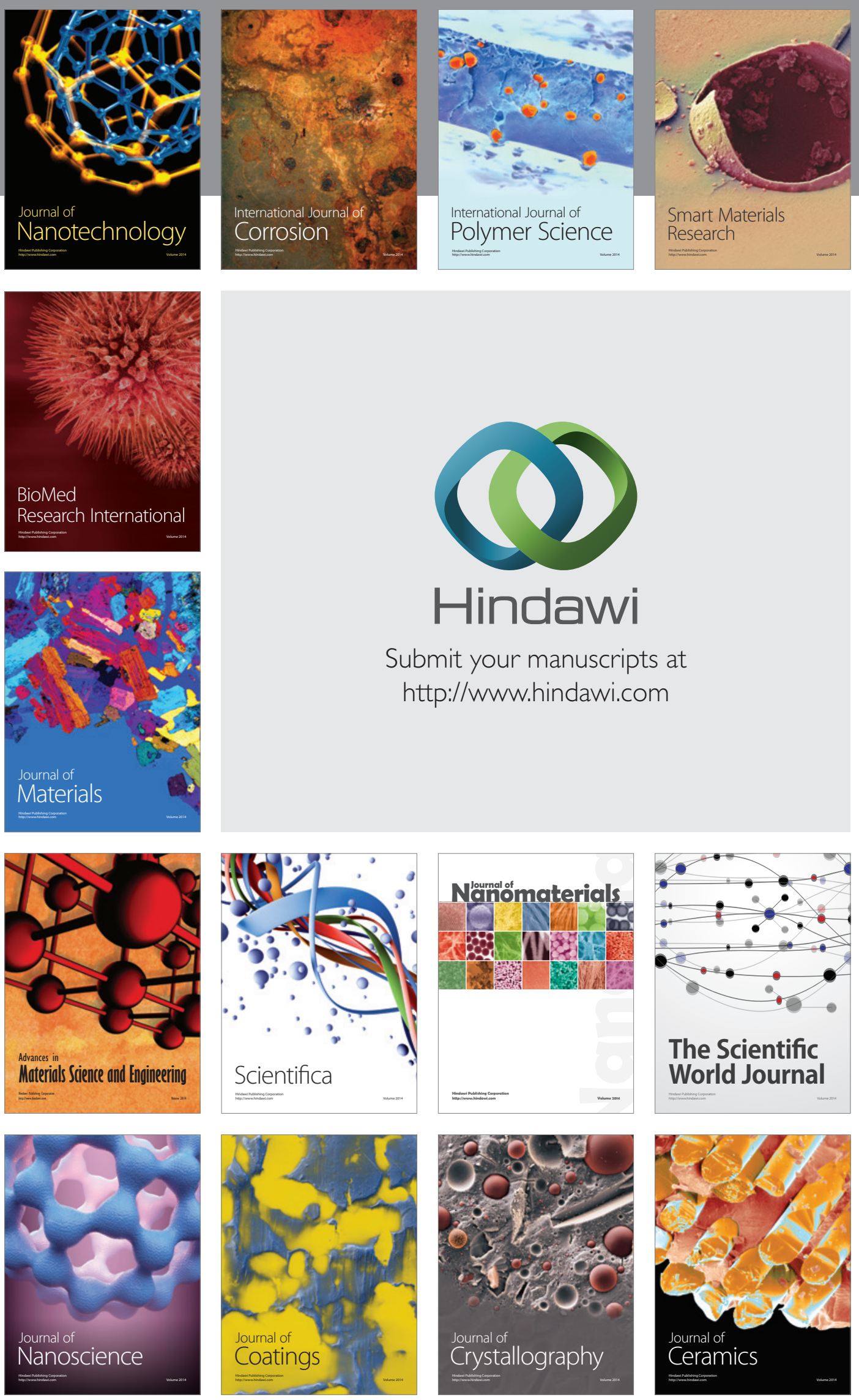

The Scientific World Journal

Submit your manuscripts at

http://www.hindawi.com

\section{World Journal}

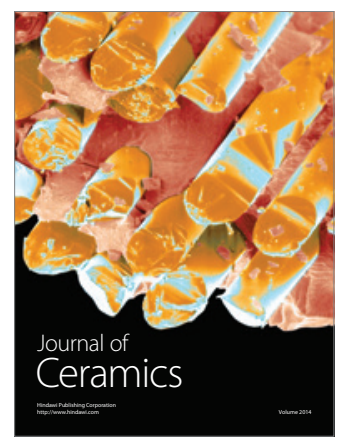

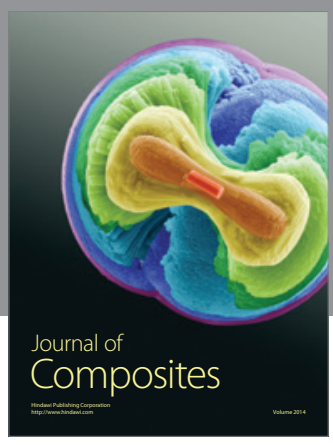
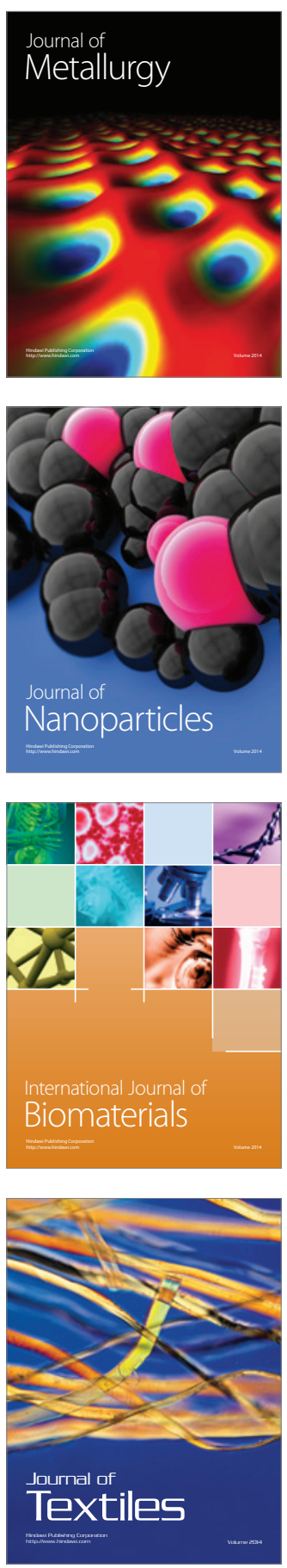